\title{
REVIEW
}

\section{Clinical review: Glucose control in severely burned patients - current best practice}

\author{
Marc G Jeschke*
}

\begin{abstract}
Tight glucose control changed the way many burn centers practice burn ICU care. However, after the initial impressive data, various clinical trials followed that showed mixed results. The objective of the present review is to discuss recent studies in the area of burn and critical care, and to identify the current best practice for current burn care providers. We reviewed relevant publications from PubMed and selected high-impact publications on tight glycemic control in various patient populations with a focus on burn patients. We conclude that in burns there seems to be a signal that insulin administration to a target range of 130 to $150 \mathrm{mg} / \mathrm{dl}$ is beneficial in terms of morbidity and mortality without the risk of hypoglycemia.
\end{abstract}

\section{Background}

A burn injury represents one of the most severe forms of trauma and occurs in more than 2 million people in North America each year [1]. According to the World Health Organization, there are an estimated worldwide 330,000 deaths per year related to thermal injury [2]. A severe burn is an extremely devastating injury that affects nearly every organ system, leading to significant morbidity and mortality, and is accompanied by a hallmark hypermetabolic response [3,4]. This post-burn hypermetabolism is initiated to provide sufficient energy for maintaining organ function and whole-body homeostasis under demanding trauma conditions [5-8]. Unfortunately, prolonged hypermetabolism becomes detrimental and is associated with vast catabolism multiorgan failure, and death $[3,9,10]$. Various studies have found that the metabolic need of a burn patient is the highest of any medical state, approaching $140 \%$ of that predicted. The

*Correspondence: marc.jeschke@sunnybrook.ca

Ross-Tilley Burn Centre, Sunnybrook Health Sciences Centre, Department of Surgery, Division of Plastic Surgery, University of Toronto, 2075 Bayview Avenue, Room D704, Toronto, Ontario, Canada M4N 3M5 hypermetabolic response involves a vast number of pathways, but there is one that appears to most profoundly affect post-burn outcomes: glucose metabolism with insulin resistance (IR) and hyperglycemia [11-14].

Stress-induced diabetes, with hyperglycemia and IR, during acute hospitalization is a hallmark of severely burned patients and a common pathophysiological phenomenon [4]. During the early phases of post burn, hyperglycemia occurs as a result of an increased rate of glucose appearance along with an impaired tissue extraction of glucose, leading to an increase of glucose and lactate $[8,15]$. Stress-induced hyperglycemia is associated with adverse clinical outcomes after severe burn; specifically, burned patients with poor glucose control have a significantly higher incidence of bacteremia/ fungemia, enhanced catabolism, and mortality $[11,12]$. Control of glucose is therefore essential in terms of improving post-burn outcomes. However, there has been profound controversy about tight euglycemic control in critically ill patients as well as burn patients, and the aim of this review article is to discuss the current best practice for glucose control in burn patients with a background of current critical care studies.

\section{Current evidence: tight euglycemic control in critically ill patients}

Van den Berghe and colleagues described the detrimental effect of hyperglycemia in critically ill patients, and they conducted multiple clinical studies investigating the effect of decreased glucose levels on outcome [16-20]. These authors showed that insulin administered to maintain glucose at levels $<110 \mathrm{mg} / \mathrm{dl}$ decreased mortality, incidence of infections, sepsis and sepsis-associated multiorgan failure in surgically critically ill patients [19]. In an intent-to-treat study, the effects of insulin in medical ICU patients were investigated [18]. Intensive insulin therapy significantly reduced newly acquired kidney injury, accelerated weaning from mechanical ventilation, and accelerated discharge from the ICU and the hospital. In a follow-up study, the authors showed that insulin given during the acute phase not only improved acute hospital outcomes but also improved long-term rehabilitation and social reintegration of 
critically ill patients over a period of 1 year [21,22]. The same group then published data on the effect of intensive insulin treatment in pediatric ICU patients, and the authors showed that targeting of blood glucose concentrations to age-adjusted normal fasting concentrations improved the short-term outcome of patients in the pediatric ICU. Most recently, the authors showed in a long-term follow-up study that children who had been treated with intensive insulin therapy during their ICU stay improved motor coordination and cognitive flexibility, but overall tight glycemic control did not affect IQ compared with control patients [23].

Various unicenter and multicenter studies followed the Leuven trials to determine whether tight euglycemic control improves outcomes in a different setting. The results of these trials were mixed, with some showing benefits with the use of euglycemic control $[14,24,25]$ while others demonstrated detrimental effects associated with tight euglycemic control [26,27].

In a multicenter trial in Europe - Efficacy of Volume Substitution and Insulin Therapy in Severe Sepsis (VISEP) - the effect of insulin administration on morbidity and mortality in patients with severe infections and sepsis was investigated [26]. The authors found that insulin administration did not affect mortality, but the rate of severe hypoglycemia was fourfold higher in the intensive therapy group when compared with the conventional therapy group [26]. The authors concluded that intensive insulin therapy is not beneficial; in contrast, it is associated with an increased risk of hypoglycemia. As this study had only about 800 patients, a large multicenter trial was initiated to address whether intensive insulin therapy/tight euglycemic control is associated with improved outcomes. The GLUCONTROL trial examined the effect of intensive insulin therapy compared with conventional glucose control on mortality of patients admitted to 21 medical-surgical ICUs in Europe. The trial was designed to admit 3,500 patients, but it was stopped early because of a high number of protocol violations after the recruitment of 1,000 patients with no significant differences in ICU mortality (17.2\% vs. $15.3 \%)$ and an increased rate of hypoglycemia in the insulin group ( $8.7 \%$ vs. $2.7 \%)$ [28].

To end the substantial discussion as to whether tight euglycemic control is beneficial, a large multicenter trial was initiated. The NICE SUGAR trial enrolled more than 6,000 patients and failed to show beneficial outcomes for critically ill patients with intensive insulin therapy [27]; in contrast, the authors found that intensive glucose control increased mortality among adults in the ICU: a blood glucose target $\leq 180 \mathrm{mg} / \mathrm{dl}$ resulted in lower mortality than did a target of 81 to $108 \mathrm{mg} / \mathrm{dl}$ [27]. The latest trial was conducted in pediatric cardiac surgery patients [29]. This trial was a two-center, prospective, randomized trial that enrolled 980 children who underwent surgery with cardiopulmonary bypass. The authors found that despite early, adequate, and good glucose control, in patients receiving insulin there was no difference in mortality, infection, length of stay, or measures of organ failure, as compared with standard care. Lastly, various metaanalyses did not show any benefit associated with insulin therapy; and Preiser and colleagues even suggested that it is not the insulin per se but the protocolized care that improved outcome of tight euglycemic control [28]. A recent study in renal transplantation patients did not find any difference between the intensive insulin glycemic group and control patients [30].

The reasons for these discrepancies in outcomes are not entirely clear and defined. One possible explanation could be that the Leuven center gives high amounts of calories, and a significant amount of these calories as parenteral nutrition. Perhaps intensive insulin therapy improves outcomes in these circumstances, but there could be other factors present in the Leuven ICU population that are not present in other populations.. However, to discuss these discrepancies is not the scope of this review.

A common finding of all intensive insulin trials was an increased incidence of hypoglycemia. Despite the common knowledge to avoid hypoglycemia, little is known about its consequences. The VISEP trial found a fourfold higher incidence of hypoglycemia; the GLUCONTROL trial found a threefold to fourfold higher incidence, and the NICE SUGAR trial found a similar incidence. A recent retrospective study reported the relationship between mild $(<81 \mathrm{mg} / \mathrm{dl})$ and severe $(<40 \mathrm{mg} / \mathrm{dl})$ hypoglycemic episodes and death [31], and reported in patients who had hypoglycemic episodes that their mortality was $36.6 \%$ compared with $19.7 \%$ in those who did not experience hypoglycemia. Once the authors adjusted for insulin therapy, hypoglycemia was independently associated with increased risk of death, cardiovascular death, and death due to infectious disease [31]. The NICE SUGAR trial group used their patients from the prior trial and determined whether hypoglycemia leads to an increased morbidity and mortality in ICU patients [32]. The authors were not able to prove a causal relationship between hypoglycemia and death but their data are strongly indicative that hypoglycemia in critically ill patients is associated with an increased risk of mortality.

Taking all of the data together, insulin therapy appears to have some beneficial effects in ICU patients, but by no means is it currently evident whether tight euglycemic control using intensive insulin therapy is beneficial or not. In contrast, intensive insulin therapy leads to increased episodes of hypoglycemia, which are associated with worsened outcomes of ICU patients. Current efforts are focusing on adoption and implementation of the 
original strict glycemic control guidelines as more feasible and safe guidelines $[33,34]$. What about burn patients?

\section{Tight euglycemic control in burn patients Insulin resistance and hyperglycemia post burn}

Stress-induced diabetes with hyperglycemia and IR during acute hospitalization is a hallmark of severely burned patients, and a common pathophysiological phenomenon [4]. During the early phases post burn, hyperglycemia occurs as a result of an increased rate of glucose appearance along with an impaired tissue extraction of glucose, leading to an increase of glucose and lactate $[8,15]$. This pathophysiological post-burn response is similar to the pathophysiology of type 2 diabetes, differing only in its acute onset and severity.

Of major importance is recent evidence strongly suggesting that hyperglycemia is detrimental and associated with adverse clinical outcomes in severely burned patients. Specifically, studies in burn patients indicated that hyperglycemia is associated with increased infections and sepsis, increased incidence of pneumonia, significantly increased catabolism and hypermetabolism, and, most importantly, with increased post-burn mortality [11-14,35,36].

Although the dire consequences of burn-induced hyperglycemia have been delineated, the molecular mechanisms underlying IR and hyperglycemia are not entirely defined. Accordingly, endoplasmic reticulum stress was recently identified as one of the central intracellular stress signaling pathways linking IR, hyperglycemia, and inflammation [37]. Since inflammation, IR, and hyperglycemia are central characteristics of the post-burn response [4], we investigated in a preliminary study whether a severe burn induces endoplasmic reticulum stress and the unfolded protein response in severely burned patients. As expected, we found that a severe thermal injury induces endoplasmic reticulum stress in the metabolically active tissues skin, fat, and muscle [38]. We therefore have evidence suggesting that endoplasmic reticulum stress may be central to orchestrating and inducing inflammatory and hypermetabolic responses post burn on a cellular level.

\section{Insulin administration in burn patients}

Insulin represents probably one of the most extensively studied therapeutic agents and novel applications that are being determined and developed. One of the first publications on insulin, glucose, and fat was from Allison and colleagues in The Lancet in 1968 [39]. In 1971, Hinton and Allison published a report on the use of insulin and glucose to reduce the catabolic response to burn [40]. The complex picture of the post-burn hypermetabolic response was enhanced when Wilmore and colleagues showed that catecholamines are the mediators of the hypermetabolic response inducing hyperglycemichyperinsulinemic responses [41]. The same authors found in 1976 that post-burn hepatic gluconeogenesis is the characteristic mediated by glucagon and catecholamines [9]. Several studies followed regarding the expression profiles of glucose and insulin post burn. Wolfe and colleagues showed that burn induces a hyperinsulinemic hyperglycemic response characterized by increased hepatic glucose output with decreased glucose uptake from the periphery [42-45]. They also showed that IR increases in the case of an infection or sepsis.

In terms of clinical data, the use of insulin has been intensively studied, but tight glycemic control as a concept was introduced to burns at the same time as van den Berghe and colleagues' study was published in The New England Journal of Medicine [18,19]. The first data on hyperglycemia and inadequate glucose control in burn patients were published by Gore and colleagues, who showed that hyperglycemia was associated with increased hypermetabolism, catabolism, infection/sepsis, poor wound healing, and subsequent increased mortality $[11,12]$. Pham and colleagues showed in a retrospective study in 2005 that intensive insulin therapy to maintain normoglycemia in severely burned children can be implemented in burn patients and that insulin therapy lowers infection rates and improves survival [36].

The next study was a cohort study in 152 patients from the University of Michigan, which showed that intensive insulin therapy for burn-injured patients was associated with a reduced incidence of pneumonia, ventilator-associated pneumonia, and urinary tract infection. Interestingly, these clinical data were subsequently confirmed in a burn-sepsis animal model. In this study, Gauglitz and colleagues found that insulin significantly improved survival and decreased bacterial load in this model, indicating the immunological and survival benefit of insulin therapy [46].

Two studies published in 2008 demonstrated that algorithms to ensure glycemic control are feasible and effective in titrating hyperglycemia $[47,48]$. Gibson and colleagues showed in 2009 that intensive insulin therapy was more difficult to implement than insulin therapy in surgical ICU patients, but they found in both patient populations that insulin improved survival in the ICU setting [49].

The first randomized controlled trial was published in 2010 by our group. We enrolled 239 burned pediatric patients and found that tight glycemic control significantly decreased infection and sepsis, improved organ function, and alleviated burn-induced IR compared with control patients. Due to an uneven randomization, we could not find a difference in mortality between groups $(P<0.14)$. However, this randomized controlled trial clearly indicated that insulin treatment has benefits in burn 
pediatric patients [14]. This trial was carried out in pediatric patients and there is no randomized controlled trial in adult burn patients, so the efficacy in burn adult patients has yet to be shown.

In summary, there is evidence that tight glycemic control is beneficial in burn patients. This finding is even more important in light of the fact that IR and hyperglycemia persists for about 3 years post burn and glucose control during acute hospitalization most probably alleviates long-term IR and hyperglycemia [50].

\section{Insulin as a therapeutic agent}

Over the last years it became evident that insulin not only acts as a molecule to mediate glucose control, but furthermore that insulin can act as a therapeutic agent per se. Various physiologic, biochemical, and metabolic studies were conducted using various doses of insulin. These studies showed that insulin improved muscle protein synthesis and attenuated lean body mass loss leading to improved post-burn lean body mass [44]. Insulin further improved wound healing of the burn wounds, increased protein synthesis in the skin, and accelerated donor site healing time $[43,51,52]$. In burned rabbits, insulin improved the net protein balance in scalded skin $[45,53,54]$. Insulin furthermore increased wound healing by pro-mitogenic and anti-apoptotic effects on keratinocytes and fibroblasts [51]. In addition, insulin was found to have profound antiinflammatory effects by reducing the inflammatory and acute phase responses [55-58].

One important study by Aarsland and colleagues showed that insulin does not contribute to hepatic triglyceride production, which is present in burn patients and is a major concern [59]. In several in vivo studies we found that insulin has substantial effects on hepatocytes and alleviates hepatic apoptosis, mitochondrial dysfunction, and endoplasmic reticulum stress $[46,56,58,60,61]$. The finding that insulin affects mitochondrial function was confirmed in severely burned patients. The authors found that insulin improved skeletal muscle mitochondrial state 3 oxidation [62-64]. These findings represent important results as they indicate that insulin not only affects metabolic profiles but also cellular changes, which are linked to metabolic functions $[38,60,65]$.

Following this notion, we found that insulin improves intracellular hepatic ATP, glucose, and lactate level post burn, indicating improved energy efficiency $[55,60]$. Lastly, insulin was recently shown to improve survival in a burn-sepsis two-hit model [46]. The reason for improved outcome was not only metabolic but also because of a profound effect of insulin on the immune system. Overall, insulin appears to have both cell protective anabolic effects as well as metabolic and inflammatory effects, making it a fascinating agent for the treatment of burn patients.

\section{Glucose target}

Using the envelope of the prospective randomized trial, we conducted a large cohort study and asked the question of which glucose level should be targeted [66]. We found in over 300,000 blood glucose measurements that $130 \mathrm{mg} / \mathrm{dl}$ appears to be an ideal glucose target. We hypothesized that this is due to the fact that hypoglycemia is avoided while protein glycolysation that occurs at $150 \mathrm{mg} / \mathrm{dl}$ is also avoided. We therefore recommended targeting blood glucose levels at $130 \mathrm{mg} / \mathrm{dl}$ [66]. This is in agreement with the sepsis guidelines and various meta-analyses. Finney and colleagues recommend glucose levels $\leq 140 \mathrm{mg} / \mathrm{dl}$ [24]. Preiser and Devos in their analysis summarized recent studies on glucose modulation [25]. The authors recommend that, given the hypoglycemic risks of intensive insulin therapy and the uncertainty of the ideal glucose level, an intermediate level of $140 \mathrm{mg} / \mathrm{dl}$ should be targeted. Somewhat following this recommendation is the Surviving Sepsis Campaign [67]. The authors recognized the lack of an ideal glucose range and the complications of hypoglycemic episodes, and their recommendation changed from maintaining glucose levels $<150 \mathrm{mg} / \mathrm{dl}$ [67] to $<180 \mathrm{mg} / \mathrm{dl}$ [68]. We found in burn patients, however, that a range of 130 to $150 \mathrm{mg} / \mathrm{dl}$ is an ideal glucose range because protein glycolysation is avoided as well as an increased incidence of hypoglycemia. At the Ross Tilley Burn Centre we adjusted our glucose ranges to 90 to 144 $\mathrm{mg} / \mathrm{dl}$ and found that this represents an effective yet safe range (Figure 1).

\section{Hypoglycemia, risk, incidence, and treatment}

As mentioned above, the downside of tight euglycemic control is the increased risk of hypoglycemia. There are two levels of hypoglycemia: moderate hypoglycemia, defined as blood glucose levels $<60 \mathrm{mg} / \mathrm{dl}$; and severe hypoglycemia, defined as glucose levels $<40 \mathrm{mg} / \mathrm{dl}$. In general, hypoglycemia is considered detrimental and dangerous, and current guidelines in critically ill, septic, trauma, and burn patients are now calling for less strict glucose ranges of glucose levels 130 to $150 \mathrm{mg} / \mathrm{dl}[25,66]$. Despite the caution to avoid hypoglycemic episodes, little is known about the short-term and long-term consequences of hypoglycemic episodes in the critical care setting, or even less so for burn patients. More importantly, it is currently unknown whether brief periods of hypoglycemia lead to increased morbidity and mortality, or worsens clinical outcomes.

We conducted a study in which we determined the incidence of hypoglycemic episodes post burn and whether hypoglycemia is, in fact, associated with increased post-burn morbidity and mortality (Jeschke MG, Pinto R, Kraft R, Finnerty CC, and Herndon DN. manuscript in revision). We found in pediatric burn patients that hypoglycemia is associated with significantly 


\title{
Sunnybrook
}

\author{
HEALTH SCIENCES CENTRE
}

\section{PHYSICIAN'S ORDERS}

\section{PHYSICIAN'S ORDERS}

All orders shall be DATED. TIMED, and SIGNED

All medication orders shall be written in the GENERIC or non-proprietary name.

All orders shall be written legibly using ball point pen.

PATIENT IDENTIFICATION

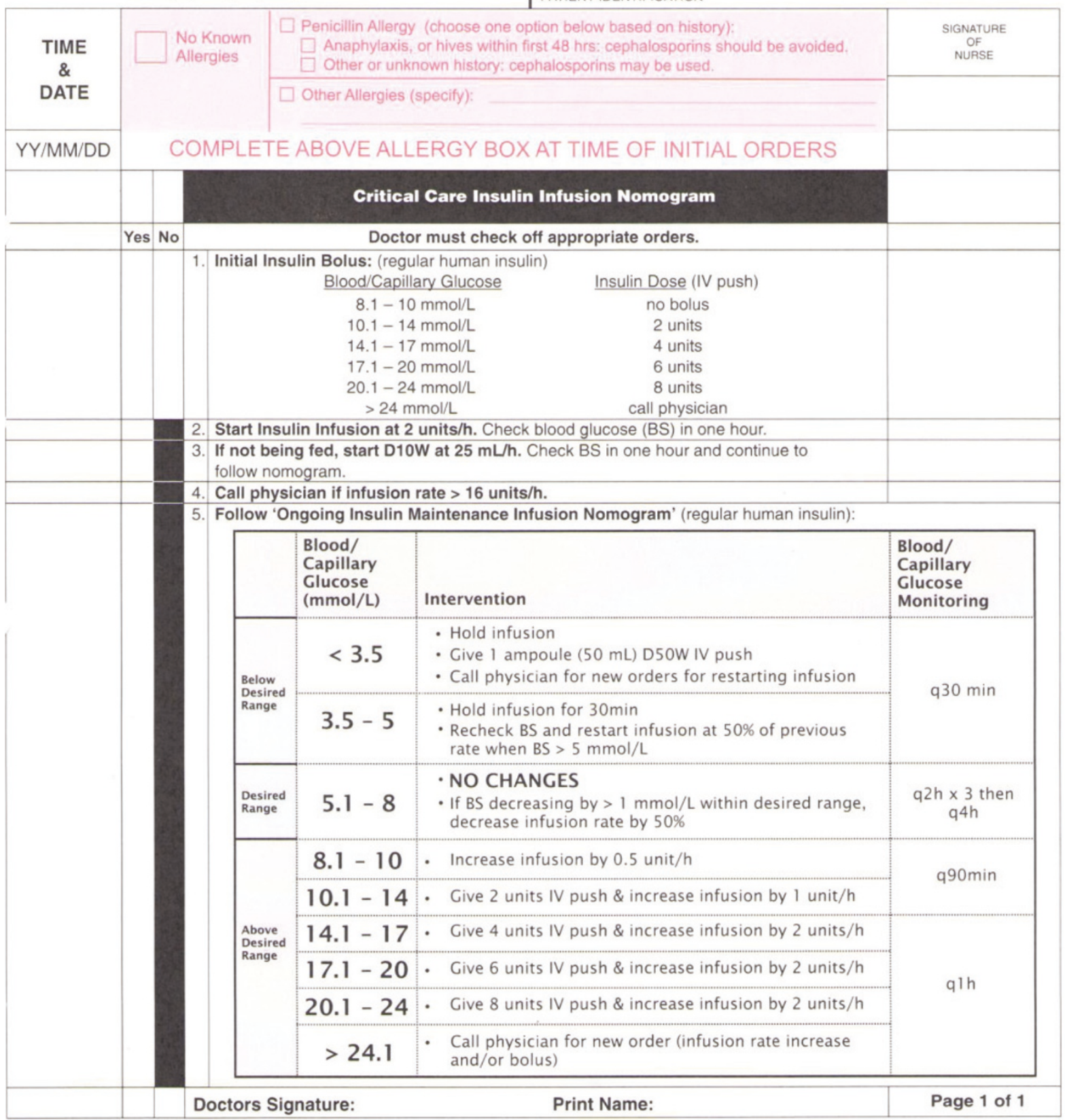

PR $36075(05-2006)$

DISTRIBUTION

White Original - Chart

Yellow Copy - Pharmacy

Figure 1. Protocol for glucose control - hyperglycemia and hypoglycemia - currently used at the Ross-Tilley Burn Centre. D50W, dextrose in water (50\%); IV, intravenous. 
increased post-burn morbidity and mortality. It was furthermore interesting that the incidence of hypoglycemia was significantly increased in patients who were enrolled in the intensive insulin trial, confirming the risk of tight euglycemic control shown in other various trials [14,26,27,69-71]. Van den Berghe and colleagues report an incidence of approximately $5 \%$ in the critically ill patient population $[18,19]$, while other trials report an incidence ranging from 10 to $25 \%[26,27,71]$. The incidence of hypoglycemia in burn patients in our study (26\%) was higher than in other patient populations. We believe that the reason for increased hypoglycemia is due to the nature of the injury, because maintaining tight glycemic ranges is difficult owing to feeding interruptions and variability in feeds; in addition, as burn patients require weekly operations and daily dressing changes, the enteral nutrition occasionally has to be stopped, which leads to disruption of gastrointestinal motility, and difficult adjustments $[4,56,66]$.

In summary, our study showed that one or more episodes of hypoglycemia were associated with clinical adverse outcomes. However, it is important to emphasize that glycemic control does improve outcomes in severely burned children but it is imperative to use management strategies that minimize iatrogenic hypoglycemia - and until further outcome is evidenced, practitioners wishing to employ this management should consider using consistent, validated approaches. In case hypoglycemia occurs, in our burn centre we implemented infusing $50 \mathrm{~cm}^{3}$ dextrose in water (50\%) intravenously and readjusting the insulin infusion protocol (see Figure 1).

\section{Novel areas of clinical investigations}

By no means have all questions regarding glucose control been addressed or determined. Several novel areas within glucose control have arisen looking at various effects, treatments, or outcomes post burn. A relatively novel topic being investigated is glucose variability. Pidcoke and colleagues showed in 2009 for 49 burn patients with burns over $20 \%$ total body surface area that high glucose variability ( $>50 \%$ of values outside 80 to $110 \mathrm{mg} / \mathrm{dl}$ ) is associated with increased mortality [72]. This initial study was recently confirmed by Pisarchik and colleagues [73]. In a retrospective analysis, the authors analyzed blood glucose data of 172 burn patients who did not have pre-existing diabetes. The authors found that high glucose variability was associated with infections/sepsis and mortality; interestingly, a high glucose variability was predictive for these adverse outcomes even if the glucose level was within the target range. Whether increased glucose variability is a sign of a sick/largely burned patient or is a sign of metabolic alterations indicating that something is wrong with the patient, serving as a predictor, is currently not understood.
A second area of interest is how we measure glucose levels. In 2008, Mann and colleagues showed in surgical, trauma, medical, cardiothoracic, and burn patients that there are significant differences in glucose levels depending on the device used [48]. The authors tested three common glucometer brands and compared these results with laboratory results. The authors found that glucometer results were higher when compared with laboratory values and that hematocrit profoundly affected the readout of various devices [74]. The same group followed up with another study in 2010, and very impressively showed that glucose measurements should be conducted via one biochemical analysis because anemia has been shown to cause hypoglycemia in ICUs due to error in single-channel glucometers [75]. These results clearly indicate that our point-of-care measurements are wrong and we base treatment decision on the wrong information. There has been some strong effort to change openloop point-of-care glucose testing to closed-loop testing, which would avoid these significant errors. A recent review by Damiano and colleagues compares three closedloop models and indicates strengths and weaknesses [76].

Lastly, novel areas in the field of glucose control involve anti-diabetic agents that can control gluconeogenesis or glucose uptake without causing hypoglycemia. Agents that are being currently tested involve glucagon-like peptide-1 [77], metformin [78-80], peroxisome proliferatoractivated receptor alpha agonist [81,82], and oral insulin (unpublished observations), but none of these agents are gold standards at the present time.

\section{Conclusion}

Current studies and data indicate that insulin has beneficial effects in the treatment of severely burned patients. Insulin administration is associated with increased episodes of hypoglycemia. We and others have recently shown that hypoglycemia in burn patients is associated with worse clinical outcomes and that hypoglycemia should be avoided if possible. We conducted a study to determine the ideal glucose target in severely burned children. We found that $130 \mathrm{mg} / \mathrm{dl}$ is the best glucose target because of the glucose levels being $<150$ to $160 \mathrm{mg} / \mathrm{dl}$ but avoiding detrimental hypoglycemia. Given recommendations from the critical care literature and other patient populations, it appears that a glucose range of 90 to $140 \mathrm{mg} / \mathrm{dl}$ seems ideal for treating burn patients. In comparison, the current surviving sepsis guidelines are calling for glucose $<180 \mathrm{mg} / \mathrm{dl}$ [68].

\section{Abbreviations}

IR, insulin resistance; NICE-SUGAR, Normoglycemia in Intensive Care Evaluation - Survival Using Glucose Algorithm Regulation; VISEP, Efficacy of Volume Substitution and Insulin Therapy in Severe Sepsis.

\section{Competing interests}

The author declares that he has no competing interests. 


\section{Author's contributions}

MGJ designed the study, acquired, analyzed and interpreted the results, drafted and revised the manuscript and was responsible for funding.

\section{Acknowledgements}

This work is supported by grants from the Canadian Institutes of Health Research (123336), the CFI Leader's Opportunity Fund (Project 25407), the National Institutes of Health (R01 GM087285-01), and the Physicians'Services Incorporated Foundation - Health Research Grant Program.

Published: 25 July 2013

\section{References}

1. Bringham PA, McLoughlin E: Burn incidence and medical care use in the United States: estimates, trends and data sources. J Burn Care Rehabil 1996, 17:95-107.

2. World Health Organization. A Graphical Overview of the Global Burden of Injuries. The Injury Chart Book. Volume 29. Geneva: WHO; 2002.

3. Herndon DN, Tompkins RG: Support of the metabolic response to burn injury. Lancet 2004, 363:1895-1902.

4. Jeschke MG, Chinkes DL, Finnerty CC, Kulp G, Suman OE, Norbury WB, Branski LK, Gauglitz GG, Mlcak RP, Herndon DN: Pathophysiologic response to severe burn injury. Ann Surg 2008, 248:387-401.

5. Wolfe RR, Durkot MJ, Allsop JR, Burke JF: Glucose metabolism in severely burned patients. Metabolism 1979, 28:1031-1039.

6. Wolfe RR, Herndon DN, Peters EJ, Jahoor F, Desai MH, Holland OB: Regulation of lipolysis in severely burned children. Ann Surg 1987, 206:214-221.

7. Wolfe RR, Jahoor F, Hartl WH: Protein and amino acid metabolism after injury. Diabetes Metab Rev 1989, 5:149-164.

8. Wolfe RR, Miller HI, Spitzer JJ: Glucose and lactate kinetics in burn shock. Am J Physiol 1977, 232:E415-E418.

9. Wilmore DW: Hormonal responses and their effect on metabolism. Surg Clin North Am 1976, 56:999-1018.

10. Wilmore DW, Aulick LH: Metabolic changes in burned patients. Surg Clin North Am 1978, 58:1173-1187.

11. Gore DC, Chinkes D, Heggers J, Herndon DN, Wolf SE, Desai M: Association of hyperglycemia with increased mortality after severe burn injury. J Trauma 2001, 51:540-544.

12. Gore DC, Chinkes DL, Hart DW, Wolf SE, Herndon DN, Sanford AP: Hyperglycemia exacerbates muscle protein catabolism in burn-injured patients. Crit Care Med 2002, 30:2438-2442

13. Hemmila MR, Taddonio MA, Arbabi S, Maggio PM, Wahl WL: Intensive insulin therapy is associated with reduced infectious complications in burn patients. Surgery 2008, 144:629-635.

14. Jeschke MG, Kulp GA, Kraft R, Finnerty CC, Mlcak R, Lee JO, Herndon DN: Intensive insulin therapy in severely burned pediatric patients: a prospective randomized trial. Am J Respir Crit Care Med 2010, 182:351-359.

15. Gore DC, Ferrando A, Barnett J, Wolf SE, Desai M, Herndon DN, Goodwin C, Wolfe RR: Influence of glucose kinetics on plasma lactate concentration and energy expenditure in severely burned patients. J Trauma 2000, 49:673-678.

16. Van den Berghe G: Increased mortality associated with growth hormone treatment in critically ill adults. N Engl J Med 2000, 342:135; author reply 135-136.

17. Van den Berghe G: Insulin therapy for the critically ill patient. Clin Cornerstone 2003, 5:56-63.

18. Van den Berghe G, Wilmer A, Hermans G, Meersseman W, Wouters PJ, Milants I, Van Wijngaerden E, Bobbaers H, Bouillon R: Intensive insulin therapy in the medical ICU. N Engl J Med 2006, 354:449-461.

19. van den Berghe G, Wouters P, Weekers F, Verwaest C, Bruyninckx F, Schetz M Vlasselaers D, Ferdinande P, Lauwers P, Bouillon R: Intensive insulin therapy in the critically ill patients. N Engl J Med 2001, 345:1359-1367.

20. Van den Berghe $\mathrm{GH}$ : Role of intravenous insulin therapy in critically ill patients. Endocr Pract 2004, 10(Suppl 2):17-20.

21. Ellger B, Debaveye Y, Vanhorebeek I, Langouche L, Giulietti A, Van Etten E, Herijgers P, Mathieu C, Van den Berghe G: Survival benefits of intensive insulin therapy in critical illness: impact of maintaining normoglycemia versus glycemia-independent actions of insulin. Diabetes 2006 55:1096-1105.

22. Ingels C, Debaveye Y, Milants I, Buelens E, Peeraer A, Devriendt Y, Vanhoutte T, Van Damme A, Schetz M, Wouters PJ, Van den Berghe G: Strict blood glucose control with insulin during intensive care after cardiac surgery: impact on 4-years survival, dependency on medical care, and quality-of-life. Eur Heart J 2006, 27:2716-2724

23. Mesotten D, Gielen M, Sterken C, Claessens K, Hermans G, Vlasselaers D, Lemiere J, Lagae L, Gewillig M, Eyskens B, Vanhorebeek I, Wouters PJ, Van den Berghe G: Neurocognitive development of children 4 years after critical illness and treatment with tight glucose control: a randomized controlled trial. JAMA 2012, 308:1641-1650

24. Finney SJ, Zekveld C, Elia A, Evans TW: Glucose control and mortality in critically ill patients. JAMA 2003, 290:2041-2047.

25. Preiser JC, Devos P: Clinical experience with tight glucose control by intensive insulin therapy. Crit Care Med 2007, 35:S503-S507.

26. Brunkhorst FM, Engel C, Bloos F, Meier-Hellmann A, Ragaller M, Weiler N, Moerer O, Gruendling M, Oppert M, Grond S, Olthoff D, Jaschinski U, John S, Rossaint R, Welte T, Schaefer M, Kern P, Kuhnt E, Kiehntopf M, Hartog C, Natanson C, Loeffler M, Reinhart K: Intensive insulin therapy and pentastarch resuscitation in severe sepsis. N Engl J Med 2008, 358:125-139.

27. Finfer S, Chittock DR, Su SY, Blair D, Foster D, Dhingra V, Bellomo R, Cook D, Dodek P, Henderson WR, Hebert PC, Heritier S, Heyland DK, McArthur C, McDonald E, Mitchell I, Myburgh JA, Norton R, Potter J, Robinson BG, Ronco $\mathrm{JJ}$ : Intensive versus conventional glucose control in critically ill patients. NEngl J Med 2009, 360:1283-1297.

28. Preiser JC, Devos P, Ruiz-Santana S, Melot C, Annane D, Groeneveld J, lapichino G, Leverve X, Nitenberg G, Singer P, Wernerman J, Joannidis M, Stecher A, Chiolero R: A prospective randomised multi-centre controlled trial on tight glucose control by intensive insulin therapy in adult intensive care units: the Glucontrol study. Intensive Care Med 2009, 35:1738-1748

29. Agus MS, Steil GM, Wypij D, Costello JM, Laussen PC, Langer M, Alexander L L Scoppettuolo LA, Pigula FA, Charpie JR, Ohye RG, Gaies MG: Tight glycemic control versus standard care after pediatric cardiac surgery. N Engl J Med 2012, 367:1208-1219.

30. Hermayer KL, Egidi MF, Finch NJ, Baliga P, Lin A, Kettinger L, Biggins S, Carter RE: A randomized controlled trial to evaluate the effect of glycemic control on renal transplantation outcomes. J Clin Endocrinol Metab 2012, 97:4399-4406.

31. Egi M, Bellomo R, Stachowski E, French CJ, Hart GK, Taori G, Hegarty C, Bailey M: Hypoglycemia and outcome in critically ill patients. Mayo Clin Proc 2010 85:217-224.

32. Finfer S, Liu B, Chittock DR, Norton R, Myburgh JA, McArthur C, Mitchell I, Foster D, Dhingra V, Henderson WR, Ronco JJ, Bellomo R, Cook D, McDonald E, Dodek P, Hebert PC, Heyland DK, Robinson BG: Hypoglycemia and risk of death in critically ill patients. N Engl J Med 2012, 367:1108-1118.

33. Andel D, Kamolz LP: Blood glucose control in critically ill patients. Minerva Anestesio/ 2012, 78:975-976.

34. Schultz MJ, Harmsen RE, Korevaar JC, Abu-Hanna A, Van Braam Houckgeest F Van Der Sluijs JP, Spronk PE: Adoption and implementation of the original strict glycemic control guideline is feasible and safe in adult critically ill patients. Minerva Anestesiol 2012, 78:982-995

35. Jeschke MG, Klein D, Thasler WE, Bolder U, Schlitt HJ, Jauch KW, Weiss TS: Insulin decreases inflammatory signal transcription factor expression in primary human liver cells after LPS challenge. Mol Med 2008, 14:11-19.

36. Pham TN, Warren AJ, Phan HH, Molitor F, Greenhalgh DG, Palmieri TL: Impact of tight glycemic control in severely burned children. J Trauma 2005, 59:1148-1154.

37. Zhang K, Kaufman RJ: From endoplasmic-reticulum stress to the inflammatory response. Nature 2008, 454:455-462.

38. Jeschke MG, Finnerty CC, Herndon DN, Song J, Boehning D, Tompkins RG, Baker HV, Gauglitz GG: Severe injury is associated with insulin resistance, endoplasmic reticulum stress response, and unfolded protein response. Ann Surg 2012, 255:370-378.

39. Allison SP, Hinton P, Chamberlain MJ: Intravenous glucose-tolerance, insulin, and free-fatty-acid levels in burned patients. Lancet 1968, 2:1113-1116.

40. Hinton P, Allison SP: Insulin and glucose to reduce catabolic response to burns. Lancet 1971, 1:1247.

41. Wilmore DW, Long JM, Mason AD, Jr, Skreen RW, Pruitt BA, Jr: Catecholamines: mediator of the hypermetabolic response to thermal injury. Ann Surg 1974, 180:653-669.

42. Ferrando AA, Chinkes DL, Wolf SE, Matin S, Herndon DN, Wolfe RR: A submaximal dose of insulin promotes net skeletal muscle protein synthesis in patients with severe burns. Ann Surg 1999, 229:11-18. 
43. Pierre EJ, Barrow RE, Hawkins HK, Nguyen TT, Sakurai Y, Desai M, Wolfe RR, Herndon DN: Effects of insulin on wound healing. J Trauma 1998, 44:342-345

44. Thomas SJ, Morimoto K, Herndon DN, Ferrando AA, Wolfe RR, Klein D, Wolf SE: The effect of prolonged euglycemic hyperinsulinemia on lean body mass after severe burn. Surgery 2002, 132:341-347.

45. Zhang XJ, Chinkes DL, Wolf SE, Wolfe RR: Insulin but not growth hormone stimulates protein anabolism in skin would and muscle. Am J Physio/ 1999 276:E712-E720.

46. Gauglitz GG, Toliver-Kinsky TE, Williams FN, Song J, Cui W, Herndon DN, Jeschke MG: Insulin increases resistance to burn wound infectionassociated sepsis. Crit Care Med 2010, 38:202-208.

47. Cochran A, Davis L, Morris SE, Saffle JR: Safety and efficacy of an intensive insulin protocol in a burn-trauma intensive care unit. J Burn Care Res 2008, 29:187-191.

48. Mann EA, Pidcoke HF, Salinas J, Holcomb JB, Wolf SE, Wade CE: The impact of intensive insulin protocols and restrictive blood transfusion strategies on glucose measurement in American Burn Association ( $A B A$ ) verified burn centers. J Burn Care Res 2008, 29:718-723.

49. Gibson BR, Galiatsatos P, Rabiee A, Eaton L, Abu-Hamdah R, Christmas C, Milner SM, Andersen DK, Elahi D: Intensive insulin therapy confers a similar survival benefit in the burn intensive care unit to the surgical intensive care unit. Surgery 2009, 146:922-930.

50. Gauglitz GG, Herndon DN, Kulp GA, Meyer WJ, 3rd, Jeschke MG: Abnormal insulin sensitivity persists up to three years in pediatric patients postburn. J Clin Endocrinol Metab 2009, 94:1656-1664.

51. Pierre E, Barrow RE, Sakurai Y, Wolfe RR, Herndon DN: Structural effects of insulin on wound healing. Plastic Surg 1996, 36:743-745.

52. Tuvdendorj D, Zhang XJ, Chinkes DL, Aarsland A, Kulp GA, Jeschke MG, Herndon DN: Intensive insulin treatment increases donor site wound protein synthesis in burn patients. Surgery 2011, 149:512-518.

53. Zhang XJ, Chinkes DL, Irtun O, Wolfe RR: Anabolic action of insulin on skin wound protein is augmented by exogenous amino acids. Am J Physiol Endocrinol Metab 2002, 282:E1308-E1315.

54. Zhang XJ, Chinkes DL, Wu Z, Martini WZ, Wolfe RR: Fractional synthesis rates of DNA and protein in rabbit skin are not correlated. J Nutr 2004, 134:2401-2406.

55. Jeschke MG, Klein D, Bolder $U$, Einspanier R: Insulin attenuates the systemic inflammatory response in endotoxemic rats. Endocrinology 2004, 145:4084-4093.

56. Jeschke MG, Klein D, Herndon DN: Insulin treatment improves the systemic inflammatory reaction to severe trauma. Ann Surg 2004, 239:553-560.

57. Jeschke MG, Rensing H, Klein D, Schubert T, Mautes AE, Bolder U, Croner RS: Insulin prevents liver damage and preserves liver function in lipopolysaccharide-induced endotoxemic rats. J Hepatol 2005, 42:870-879.

58. Klein D, Schubert T, Horch RE, Jauch KW, Jeschke MG: Insulin treatment improves hepatic morphology and function through modulation of hepatic signals after severe trauma. Ann Surg 2004, 240:340-349.

59. Aarsland A, Chinkes D, Wolfe RR: Contributions of de novo synthesis of fatty acids to total VLDL-triglyceride secretion during prolonged hyperglycemia/hyperinsulinemia in normal man. J Clin Invest 1996, 98:2008-2017

60. Jeschke MG, Kraft R, Song J, Gauglitz GG, Cox RA, Brooks NC, Finnerty CC, Kulp GA, Herndon DN, Boehning D: Insulin protects against hepatic damage postburn. Mol Med 2011, 17:516-522.

61. Gauglitz GG, Halder S, Boehning DF, Kulp GA, Herndon DN, Barral JM, Jeschke MG: Post-burn hepatic insulin resistance is associated with endoplasmic reticulum (ER) stress. Shock 2010, 33:299-305.

62. Cree MG, Aarsland A, Herndon DN, Wolfe RR: Role of fat metabolism in burn trauma-induced skeletal muscle insulin resistance. Crit Care Med 2007 35:S476-\$483

63. Cree MG, Fram RY, Herndon DN, Qian T, Angel C, Green JM, Mlcak R, Aarsland A, Wolfe RR: Human mitochondrial oxidative capacity is acutely impaired after burn trauma. Am J Surg 2008, 196:234-239.

64. Cree MG, Zwetsloot JJ, Herndon DN, Newcomer BR, Fram RY, Angel C, Green JM, Dohm GL, Sun D, Aarsland A, Wolfe RR: Insulin sensitivity is related to fat oxidation and protein kinase $C$ activity in children with acute burn injury. J Burn Care Res 2008, 29:585-594.

65. Jeschke MG, Boehning D: Endoplasmic reticulum stress and insulin resistance post-trauma: similarities to type 2 diabetes. J Cell Mol Med 2012, 16:437-444.
66. Jeschke MG, Kraft R, Emdad F, Kulp GA, Williams FN, Herndon DN: Glucose control in severely thermally injured pediatric patients: what glucose range should be the target? Ann Surg 2010, 252:521-528.

67. Dellinger RP, Levy MM, Carlet JM, Bion J, Parker MM, Jaeschke R, Reinhart K, Angus DC, Brun-Buisson C, Beale R, Calandra T, Dhainaut JF, Gerlach H, Harvey M, Marini JJ, Marshall J, Ranieri M, Ramsay G, Sevransky J, Thompson BT, Townsend S, Vender JS, Zimmerman JL, Vincent JL: Surviving Sepsis Campaign: international guidelines for management of severe sepsis and septic shock: 2008. Crit Care Med 2008, 36:296-327.

68. Dellinger RP, Levy MM, Rhodes A, Annane D, Gerlach H, Opal SM, Sevransky JE, Sprung CL, Douglas IS, Jaeschke R, Osborn TM, Nunnally ME, Townsend SR, Reinhart K, Kleinpell RM, Angus DC, Deutschman CS, Machado FR, Rubenfeld GD, Webb SA, Beale RJ, Vincent JL, Moreno R: Surviving sepsis campaign: international guidelines for management of severe sepsis and septic shock: 2012. Crit Care Med 2013, 41:580-637.

69. Langouche L, Vanhorebeek I, Van den Berghe G: Therapy insight: the effect of tight glycemic control in acute illness. Nat Clin Pract Endocrinol Metab 2007, 3:270-278.

70. Van den Berghe G, Wouters PJ, Bouillon R, Weekers F, Verwaest C, Schetz M, Vlasselaers D, Ferdinande P, Lauwers P: Outcome benefit of intensive insulin therapy in the critically ill: insulin dose versus glycemic control. Crit Care Med 2003, 31:359-366.

71. Vlasselaers D, Milants I, Desmet L, Wouters PJ, Vanhorebeek I, van den Heuvel I, Mesotten D, Casaer MP, Meyfroidt G, Ingels C, Muller J, Van Cromphaut S, Schetz M, Van den Berghe G: Intensive insulin therapy for patients in paediatric intensive care: a prospective, randomised controlled study. Lancet 2009, 373:547-556.

72. Pidcoke HF, Wanek SM, Rohleder LS, Holcomb JB, Wolf SE, Wade CE: Glucose variability is associated with high mortality after severe burn. J Trauma 2009, 67:990-995

73. Pisarchik AN, Pochepen ON, Pisarchyk LA: Increasing blood glucose variability is a precursor of sepsis and mortality in burned patients. PLoS One 2012, 7:e46582.

74. Mann EA, Salinas J, Pidcoke HF, Wolf SE, Holcomb JB, Wade CE: Error rates resulting from anemia can be corrected in multiple commonly used point-of-care glucometers. J Trauma 2008, 64:15-21.

75. Pidcoke HF, Wade CE, Mann EA, Salinas J, Cohee BM, Holcomb JB, Wolf SE: Anemia causes hypoglycemia in intensive care unit patients due to error in single-channel glucometers: methods of reducing patient risk. Crit Care Med 2010, 38:471-476.

76. Damiano ER, El-Khatib FH, Zheng H, Nathan DM, Russell SJ: A comparative effectiveness analysis of three continuous glucose monitors. Diabetes Care 2013, 36:251-259.

77. Mecott GA, Herndon DN, Kulp GA, Brooks NC, Al-Mousawi AM, Kraft R, Rivero HG, Williams FN, Branski LK, Jeschke MG: The use of exenatide in severely burned pediatric patients. Crit Care 2010, 14:R153.

78. Gore DC, Herndon DN, Wolfe RR: Comparison of peripheral metabolic effects of insulin and metformin following severe burn injury. J Trauma 2005, 59:316-323.

79. Gore DC, Wolf SE, Herndon DN, Wolfe RR: Metformin blunts stress-induced hyperglycemia after thermal injury. J Trauma 2003, 54:555-561.

80. Gore DC, Wolf SE, Sanford A, Herndon DN, Wolfe RR: Influence of metformin on glucose intolerance and muscle catabolism following severe burn injury. Ann Surg 2005, 241:334-342.

81. Cree MG, Newcomer BR, Herndon DN, Qian T, Sun D, Morio B, Zwetsloot J, Dohm GL, Fram RY, Mlcak RP, Aarsland A, Wolfe RR: PPAR-alpha agonism improves whole body and muscle mitochondrial fat oxidation, but does not alter intracellular fat concentrations in burn trauma children in a randomized controlled trial. Nutr Metab (Lond) 2007, 4:9

82. Elijah IE, Borsheim E, Maybauer DM, Finnerty CC, Herndon DN, Maybauer MO: Role of the PPAR-alpha agonist fenofibrate in severe pediatric burn. Burns 2012, 38:481-486.

doi:10.1186/cc12678

Cite this article as: Jeschke MG: Clinical review: Glucose control in severely burned patients - current best practice. Critical Care 2013, 17:232. 